\title{
KORELASI KONTROL DIRI DENGAN PERILAKU AGRESIF PADA REMAJA LAKI-LAKI PEMINUM MIRAS (Studi Kontekstual Pada Remaja Di Jemaat GPM Imanuel OSM- AMBON)
}

\author{
Salomina Patty, Prisca Diantra Sampe \\ Guru SMA Swasta Kristen YPKPM Ambon \\ salominapatty6@gmail.com
}

\begin{abstract}
The study aims to know empirically the relationship between self control and the aggressive behavior of young male drinkers. The hypothesis that researchers ask is that there is a negative connection between self-control and aggressive behaviour in adolescent male-drinkers. The better the self-control in adolescent male drinkers, the lower the aggressive behavior, and vice versa. The subject in this study amounted to 72 teenage men of alcohol drinkers with characteristics aged 15-21 years and consumed a minimum of miras already 2 months. The sampling techniques used are purposive sampling techniques.

The study used the aggressive behavior scale on adolescent male liquor and self-control scales in data retrieval. Data analysis is done using the correlation technique of Product Moment. The results showed that there was a negative link between aggressive behavior in adolescent male drinkers with self control with rxy values $=-0.497$ and $(P<0.01)$, so hypotheses in this study were accepted.
\end{abstract}

Keyword: aggressive behaviour in adolescent male drinkers, self control

\section{Pengantar}

Persoalan kenakalan remaja telah memasuki titik kritis. Selain frekuensi dan intensitasnya terus meningkat, kenakalan remaja saat ini sudah mengarah pada perbuatan yang melanggar norma, hukum, dan agama. Masalah kenakalan remaja tumbuh, berkembang dan membawa akibat-akibat tersendiri sepanjang masa yang sulit untuk dicari ujung pangkalnya. Betapa sering saat ini terdengar berita-berita kenakalan remaja melalui media massa, cetak maupun elektronik yang sudah kelewat batas. Banyak remaja yang memiliki kebiasaan buruk salah satunya adalah minum-minuman keras.

(Papalia, dkk 2009) menyatakan bahwa penggunaan alkohol termasuk jenis penyalahgunaan zat (subtance abuse). Ini adalah pola perilaku yang kurang adaptif dengan jangka waktu lebih dari sebulan dan pelakunya terus menggunakan zat tersebut walaupun tahu bahwa dirinya terancam bahaya karenanya atau menggunakannya berulang kali dalam situasi berbahaya. (Goble 1987:242) menyatakan bahwa peminum alkohol setiap kali minum selalu ingin tambah, disertai masalah-masalah kepribadian yang serius, dilukiskan sebagai kemauan yang salah arah dan sikap mementingkan diri yang ekstrem. Sikap menentang autoritas merupakan ciri umum peminum yang menjadi pecandu alkohol.

Minum-minuman keras tersebut telah menjadi masalah yang cukup meresahkan.
Banyak masalah yang ditimbulkan karena perilaku mipnum-minuman keras, baik masalah kesehatan maupun masalah sosial. Beberapa alasan yang mendorong remaja mengkonsumsi minuman keras, diantaranya adalah rasa ingin tahu, pengaruh teman, pelarian terhadap masalah atau ketidakharmonisan terhadap keluarga, kuatnya jaringan pemasaran atau pendistribusian minuman keras (Dariyo, 2003). Kebiasaan minum-minuman keras pada remaja juga berdampak pada meningkatnya dorongan perilaku agresif.

Perilaku agresif sepertinya telah menjadi sesuatu hal yang sangat biasa terjadi pada kehidupan sosial individu saat ini. Perilaku agresif adalah setiap bentuk perilaku yang dimaksudkan untuk menyakiti atau merugikan seseorang yang bertentangan dengan kemauan orang itu (Breakwell, 1998). Perilaku agresif dapat dimunculkan secara fisik maupun verbal. Perilaku agresi fisik yaitu perilaku agresi yang dilakukan dengan cara melakukan kekerasan secara fisik seperti menampar, memukul, melempar dengan benda terhadap orang lain di sekitarnya. Perilaku agresi verbal yaitu perilaku agresi yang dilakukan dengan cara mengeluarkan kata-kata untuk menyerang orang lain, dapat berupa ejekan, hinaan, caci maki. Banyak kerugian yang ditimbulkan karena perilakuperilaku agresif tersebut, baik yang berupa kerugian materi hingga kerugian yang tidak bisa dihitung dengan materi seperti pemerkosaan dan 
hilangnya nyawa seseorang. Berbagai perilaku agresif yang ditunjukkan remaja menjadi keprihatinan di kalangan masyarakat dan dunia pendidikan.

Jemaat Imanuel OSM merupakan suatu jemaat yang dari Gereja Protestan Maluku yang letak geografisnya sangat dekat dengan pusat kota Provinsi Maluku. Jemaat Imanuel OSM merupakan salah satu jemaat yang jumlah remaja laki-laki yang sangat banyak. Ada remaja yang taat dan tidak menghabiskan waktu untuk bergadang semalaman dan terlibat tauran, namun ada sebagian besar remaja yang terlibat dengan hal dimaksud. Kondisi ini mengakibatkan muncul kebiasaan-kebiasaan mengkonsumsi minuman keras pada malam hari. Efek dari konsumsi minuman keras tersebut memunculkan beberapa perilaku agresif yang merugikan banyak orang.

Berbagai perilaku agresif yang ditunjukkan remaja menjadi keprihatinan di kalangan masyarakat dan dunia pendidikan. Hasil analisis wawancara yang dilakukan peneliti pada tanggal 26 September 2015 terhadap tujuh orang remaja lingkungan jemaaat OSM, diketahui bahwa remaja yang terbiasa mengkonsumsi minum-minuman keras masih saja menunjukkan bentuk-bentuk perilaku agresif. Remaja peminum miras tersebut pada dasarnya menyadari bahwa minum-minuman keras dapat merugikan kesehatan secara fisik maupun psikologis karena efek kecanduan yang ditimbulkan setelah mengkonsumsi minuman keras. Remaja mengaku bahwa ketika dorongan untuk mengkonsumsi minumminuman keras muncul, remaja berusaha mendapatkan uang untuk membeli minumminuman keras. Cara yang dilakukan remaja merupakan bentuk-bentuk perilaku agresif, seperti memaksa teman memberikan sejumlah uang, memukul dan menendang teman yang menolak memberikan uang kepadanya. Hal tersebut dilakukan semata-mata untuk mendapatkan uang untuk dapat digunakan membeli minuman keras.

(Santrock: 2003) menyatakan bahwa dalam suatu kelompok sosial remaja laki-laki lebih menunjukkan kebiasaan minum- minuman keras. Minum-minuman keras yang mengandung alkohol secara langsung meningkatkan kemungkinan respon agresif (Pihl \& Ross, dalam Dayakisni dan Hudaniah, 2008). Contoh kasus yang menunjukkan perilaku negatif pada remaja laki-laki dilakukan oleh E (14), Tt (16), dan Yy (15) yang menggelar pesta miras dan seks, di sebuah sekolah. Sehabis menikmati miras, Yy dan Tt beradegan dewasa bersama Rus disaksikan oleh $\mathrm{E}$ sambil merekam adegan tersebut dengan menggunakan video handphone. Perbuatan para remaja ini, dilakukan di sebuah kelas yang kebetulan tidak terkunci (Valentino, 2011). Contoh kasus lain yang menunjukkan perilaku agresif pada remaja laki-laki peminum miras ditunjukkan oleh tiga orang remaja laki-laki, yaitu $F(18), Z$ (18), dan Fj (22) yang terlibat pembunuhan di sebuah pesta. Pembunuhan diawali ketika tiga orang remaja tersebut berpesta miras di sebuah kafe dan hanya disebabkan karena bersenggolan dengan $\mathrm{B}$ selaku korban (Ronal:2012).

Perilaku agresif juga dapat diartikan sebagai keinginan untuk menyakiti orang lain untuk mengekspresikan perasaan-perasaan negatif atau keinginan mencapai tujuan yang diinginkan melalui tindakan agresif (Krahe: 2005). Remaja peminum miras dengan adanya dorongan untuk mendapatkan miras dapat menunjukkan perilaku agresif yang dapat merugikan diri sendiri dan orang lain hanya demi memenuhi keinginan untuk dapat mendapatkan miras.

Hasil penelitian yang dilakukan (Siddiqah:2010) tentang pencegahan dan penanganan perilaku agresif pada remaja menunjukkan bahwa pengelolaan amarah bermanfaat secara praktis untuk membantu individu mengendalikan perilakunya, mengingat perilaku agresif merupakan masalah perilaku yang begitu kompleks. Penurunan perilaku agresif tersebut merupakan hasil dari pembiasaan, yaitu mengurangi kecenderungan spontan menjadi marah dan agresif dan meningkatkan kemampuan mengendalikan diri.

Salah satu faktor yang memengaruhi perilaku agresif menurut (Krahe:2005) adalah faktor kepribadian, salah satunya adalah kontrol diri. (Borba:2008) menyatakan bahwa dalam usaha mengendalikan perilaku, kontrol diri memberikan peran penting bagi individu. Kontrol diri menjadikan individu mampu bertindak benar. Konrol diri mampu menghentikan tindakan berbahaya dari individu. Kontrol diri berhubungan dengan sukses dalam berbagai bidang kehidupan. Hal tersebut dikuatkan oleh Synder dan Gangestad (Ghufron dan Rini, 2010) yang mengatakan bahwa konsep mengenai kontrol diri secara langsung sangat relevan untuk melihat hubungan antara pribadi 
dengan lingkungan masyarakat dalam mengatur kesan masyarakat yang sesuai dengan isyarat situasional dalam bersikap dan berpendirian yang efektif. Kemampuan mengontrol diri sebagai suatu kemampuan untuk menyusun, membimbing, mengatur dan mengarahkan bentuk perilaku yang membawa individu ke arah konsekuensi positif. Selanjutnya kemampuan mengontrol diri berkaitan dengan bagaimana seseorang mengendalikan emosi serta dorongandorongan dalam dirinya. Mengendalikan emosi berarti mendekati situasi dengan menggunakan sikap yang rasional untuk merespon situasi tersebut dan mencegah reaksi yang berlebihan. Kontrol diri akan dapat menjadikan remaja peminum miras mampu mengendalikan diri untuk melakukan tindakan yang bertentangan dengan ketentuan yang ada. Remaja peminum miras dengan kontrol diri yang baik diharapkan dapat terhindar dari perilaku agresif, namun kenyataannya kontrol diri yang dimiliki remaja laki-laki peminum mliras tidak dapat menghindarkannya dari bentuk-bentuk perilaku agresif, seperti halnya masih terdapat remaja laki-laki yang memaksa orang lain untuk memberikan sejumlah uang untuk mendapatkan miras, serta adanya kekerasan yang dilakukan remaja laki-laki peminum miras kepada orang lain sebagai usaha untuk mendapatkan miras.

\section{Tinjauan Literatur}

\subsection{Perilaku agresif pada remaja laki-laki peminum miras}

Breakwell (1998:17) menyatakan bahwa perilaku agresif adalah bentuk perilaku yang dimaksudkan untuk menyakiti atau merugikan seseorang yang bertentangan dengan kemauan orang itu. Berkowitz (2003:14) sendiri berpendapat bahwa agresivitas mengacu pada beberapa jenis perilaku, baik secara fisik maupun simbolis yang dilakukan dengan tujuan menyakiti seseorang. Kartono (2005:113) menyatakan bahwa perilaku agresif merupakan reaksi primitif dalam bentuk kemarahan hebat dan ledakan emosi tanpa terkendali, serangan, kekerasan, tingkah laku kegila-gilaan dan sadistis. Lebih lanjut Mahmudah (2010: 100) menyatakan bahwa perilaku agresif merupakan tindakan yang dimaksudkan untuk melukai orang lain.

Myers (dalam Sarwono, 2002: 297) menyatakan bahwa perilaku agresif adalah perilaku fisik atau lisan yang disengaja dengan maksud untuk menyakiti atau merugikan orang lain. (Baron dan Richardson dalam Krahe: 2005) mendefinisikan agresi sebagai segala bentuk perilaku yang dimaksudkan untuk menyakiti atau melukai makhluk hidup lain yang terdorong untuk menghindari perilaku itu. Berdasarkan uraian tersebut diketahui bahwa perilaku agresif adalah bentuk perilaku yang dimaksudkan untuk menyakiti atau merugikan orang lain.

Menurut (Berkowitz:2003) menyatakan bahwa bentuk-bentuk perilaku agresif, antara lain:

a. Agresi instrumental

Perilaku agresif instrumental merupakan perilaku agresif yang mempunyai tujuan lain di samping kejahatan. Agresi manusia merupakan usaha paksaan atau suatu upaya untuk mempertahankan kekuasaan, dominasi, atau status sosial seseorang.

b. Agresi emosional

Agresi emosional memiliki tujuan utama untuk berbuat jahat. Terlihat dari keinginan untuk menyerang seseorang ketika merasa tidak senang, memiliki keinginan untuk memukul seseorang

(Medinus dan Johnson dalam Dayakisni dan Hudaniah:2008) mengelompokkan agresi menjadi empat bentuk, yaitu:

a. Menyerang fisik, yang termasuk di dalamnya adalah memukul, mendorong, meludahi, menendang, menggigit, meninju, memarahi dan merampas.

b. Menyerang suatu objek, yang dimaksudkan disini adalah menyerang benda mati atau binatang.

c. Secara verbal atau simbolis, yang termasuk didalamnya adalah mengancam secara verbal, memburukburukkan orang lain, sikap mengancam dan sikap menuntut.

d. Pelanggaran terhadap hak milik atau menyerang daerah orang lain.

Berdasarkan uraian tersebut diketahui bahwa bentuk-bentuk perilaku agresif adalah menyerang fisik, menyerang suatu objek, agresif secara verbal atau simbolis, serta pelanggaran terhadap hak milik orang lain. 


\subsection{Kontrol diri}

(Calhoun dan Acocella:1990) mengatakan dua alasan yang mengharuskan individu mengontrol diri lebih secara kontinu. Pertama, individu hidup bersama kelompok sehingga dalam memuaskan keinginannya individu harus mengontrol perilakunya agar tidak mengganggu kenyamanan orang lain. Kedua, masyarakat mendorong individu secara konstan menyusun standar yang lebih baik dari dirinya. Ketika berusaha menyetujui tuntutan dibuatkan pengontrolan diri agar dalam proses pencapaian standar tersebut individu tidak melakukan hal-hal yang menyimpang.( Gufron dan Rini:2010) menyatakan bahwa kontrol diri merupakan kemampuan untuk menyusun, membimbing, mengatur dan mengarahkan bentuk perilaku yang dapat membawa ke arah konsekuensi positif.

Berdasarkan uraian di atas dapat disimpulkan bahwa kontrol diri adalah kemampuan individu dalam menyusun, membimbing, mengatur dan mengarahkan bentuk perilaku melalui pertimbangan kognitif sehingga dapat membuat keputusan yang diinginkan dan diterima oleh masyarakat.

(Brown, dkk dalam Smet, 1994) menyatakan bahwa jenis-jenis kontrol diri, antara lain:

a. Kontrol perilaku (behavioral control), Kontrol perilaku melibatkan kemampuan untuk mengambil tindakan yang konkrit untuk mengurangi dampak stressor.

b. Kontrol informasi (informational control), Kontrol informasi melibatkan kesempatan untuk memperoleh pengetahuan tentang kejadian yang penuh tekanan, apa yang akan terjadi, mengapa, dan apa konsekuensi yang akan terjadi.

c. Kontrol kognitif (cognitif control),

d. Kontrol kognitif adalah kemampuan untuk menggunakan proses dan strategi yang sudah dipikirkan untuk mengubah pengaruh stressor. Hal ini merupakan pemikiran tentang apa yang pada akhirnya dilakukan.

e. Kontrol keputusan (decision control), Kontrol keputusan adalah kontrol yang digunakan untuk memilih diantara prosedur alternatif.
Menurut (Averill dalam Gufron dan Rini:2010) kontrol diri dibagi menjadi tiga jenis kualitas kontrol diri yaitu:

a. Kontrol perilaku (behavior control)

Kontrol perilaku merupakan kesiapan tersedianya suatu respon yang dapat secara langsung memengaruhi atau memodifikasi suatu keadaan yang tidak menyenangkan. Kemampuan kontrol ini diperinci menjadi dua komponen, yaitu mengatur pelaksanaan (regulated administration) dan kemampuan memodifikasi stimulus (stimulus modifiability).

b. Kontrol kognitif

Kontrol kognitif merupakan kemampuan individu dalam mengolah informasi yang tidak diinginkan dengan cara menginterpretasikan, menilai atau menghubungkan suatu kejadian dalam suatu kerangka kognitif sebagai adaptasi psikologis atau mengurangi tekanan.

c. Kontrol keputusan (decesional control) Mengontrol keputusan merupakan kemampuan individu untuk memilih hasil atau suatu tindakan berdasarkan pada sesuatu yang diyakini dan disetujuinya. Kontrol diri dalam menentukan pilihan akan berfungsi, baik dengan adanya suatu kesempatan, kebebasan atau kemungkinan pada diri individu untuk memilih berbagai kemungkinan tindakan. Dalam penelitian ini jenis-jenis kontrol diri adalah kontrol perilaku (behavior control), kontrol kognitif (cognitive control), kontrol dalam mengambil keputusan (decision control), dan kontrol informasi (informational control).

\section{Metode Penelitian}

Teknik pengambilan sampel yang digunakan dalam penelitian ini yaitu purposive sampling. Adapun skala yang digunakan dalam penelitian ini yakni Skala Perilaku Agresif pada Remaja Laki-Laki Peminum Miras dan Skala Kontrol Diri. Teknik analisis data yang digunakan untuk menguji hubungan kontrol diri sebagai variabel bebas dengan perilaku agresif remaja laki-laki peminum miras sebagai variabel tergantung, dengan menggunakan teknik korelasi Product Moment dari Pearson. Adapun karakteristik populasi dalam penelitian ini 
adalah: a). Remaja di Jemaat Imanuel OSM. b). Berjenis kelamin laki-laki. c). Berusia 12-21 tahun; d) Mengkonsumsi miras minimal sudah 2 bulan.

\section{Hasil dan Pembahasan}

Hipotesis yang diajukan peneliti bahwa ada hubungan negatif antara perilaku agresif pada remaja laki-laki peminum miras dengan kontrol diri terbukti dengan nilai $r_{x y}=-0,497$ $(\mathrm{p}<0,01)$. Hasil penelitian ini menunjukkan bahwa ada hubungan negatif antara kontrol diri dengan perilaku agresif pada remaja laki-laki peminum miras. Semakin baik kontrol diri pada remaja laki-laki peminum miras, maka semakin rendah perilaku agresif, dan sebaliknya. Hasil penelitian ini mendukung pendapat yang diutarakan oleh Krahe (2005:90-100) bahwa perilaku agresif dipengaruhi oleh faktor kepribadian, salah satunya adalah kontrol diri.

Konrol diri mampu menghentikan tindakan berbahaya dari individu. Kontrol diri berhubungan dengan sukses dalam berbagai bidang kehidupan. Hal tersebut dikuatkan oleh Synder dan Gangestad (Ghufron dan Rini,2010: 22) yang mengatakan bahwa konsep mengenai kontrol diri secara langsung sangat relevan untuk melihat hubungan antara pribadi dengan lingkungan masyarakat dalam mengatur kesan masyarakat yang sesuai dengan isyarat situasional dalam bersikap dan berpendirian yang efektif. Kontrol diri akan dapat menjadikan remaja peminum miras mampu mengendalikan diri untuk melakukan tindakan yang bertentangan dengan ketentuan yang ada. Remaja peminum miras dengan kontrol diri yang baik dapat terhindar dari perilaku agresif.

(Brown, dkk dalam Slamet:1994) menyatakan bahwa salah satu jenis dari kontrol diri adalah kontrol kognitif (cognitive control) yang merupakan kemampuan individu dalam mengolah informasi yang tidak menginginkan dengan cara menginterpretasi, menilai, atau menghubungkan suatu kejadian dalam suatu kerangka kognitif sebagai adaptasi psikologis atau mengurangi tekanan. Kemampuan dalam mengontrol aspek kognitif dari individu akan dapat menjadikannya mampu mengelola respon yang akan dimunculkan terhadap sesuatu. Individu dengan kontrol diri yang baik akan dapat terhindar dari bentuk-bentuk perilaku agresif yang bertentangan dengan nilai-nilai yang berlaku di masyarakat.

Hasil penelitian ini sejalan dengan hasil penelitian yang dilakukan (Siddiqah:2010) tentang pencegahan dan penanganan perilaku agresif pada remaja menunjukkan bahwa pengelolaan amarah bermanfaat secara praktis untuk membantu individu mengendalikan perilakunya, mengingat perilaku agresif merupakan masalah perilaku yang begitu kompleks. Penurunan perilaku agresif tersebut merupakan hasil dari pembiasaan, yaitu mengurangi kecenderungan spontan menjadi marah dan agresif dan meningkatkan kemampuan mengendalikan diri.

Berdasarkan hasil data penelitian yang diperoleh, variabel perilaku agresif pada remaja laki-laki peminum miras diperoleh Mean Empirik sebesar 61,46, Mean Hipotetiknya sebesar 45 dan Standar Deviasi Hipotetiknya sebesar 15. Mean Empirik variabel perilaku agresif pada remaja laki-laki peminum miras pada area (+) 2SD. Hal ini mengindikasikan bahwa perilaku agresif pada remaja laki-laki peminum miras pada kategori tinggi, bahwa remaja laki-laki peminum miras di Jemaat Imanuel OSM menunjukkan adanya bentuk-bentuk perilaku agresif.

Hasil penelitian ini sejalan dengan penelitian tentang perilaku Agresi menurut Baron (dalam mahmudah, 2011:61) yaitu bentuk perilaku yang disengaja terhadap makhluk hidup lain dengan tujuan untuk melukai atau membinasakan dan orang yang diserang berusaha untuk menghindar, kendatipun perilaku agresif pada Remaja Jemaat Imanuel OSM sebagai subjek penelitian ini tidak samapai pada tahap membinasakan. Dalam pengertian bahwa masalah yang penting yang ditemukan pada perilaku agresif Remaja Jemaat Imanuel OSM, yaitu: a). Agresi itu perilaku : dengan demikian, segala aspek perilaku terdapat didalam agresi, misalnya : emosi dan; b). Ada unsur kesengajaan. Hasil penelitian ini juga mngungkapkan beberapa karakteristik. Karakteristik pertama, agresif merupakan tingkah laku yang bersifat membahayakan, menyakitkan, dan melukai orang lain. Karakteristik kedua adalah suatu tingkah laku yang dilakukan seseorang dengan maksud untuk melukai, menyakiti dan membahayakan oranglain yang dilakukan dengan sengaja. Karakteristik ketiga, agresif tidak hanya dilakukan untuk 
melukai korban secara fisik, tetapi juga dapat dilakukan secara psikis (psikologis) misalnya melalui kegiatan yang menghina atau menyalahkan, caci-maki dan sejenisnya. Terhadap karakteristik agresif hasil penelitian ini maka kontro diri merupakan unsur yang sangat bersinergi sebagi upaya untuk pembinaan Remaja Jemaat Imanuel OSM.

Pada variabel kontrol diri diperoleh Mean Empirik sebesar 69,57, Mean Hipotetiknya sebesar 60 dan Standar Deviasi Hipotetiknya sebesar 12. Mean Empirik variabel kontrol diri pada area (+) 1SD dari Mean Hipotetiknya. Hal ini mengindikasikan bahwa kontrol diri tergolong pada kategori sedang. Hal ini berarti remaja laki-laki di Jemaat Imanuel OSM cukup dapat mengatur dan mengarahkan perilakunya.

Sumbangan efektif variabel kontrol diri terhadap perilaku agresif pada remaja laki-laki peminum miras $24,7 \%$. Sisanya sebesar $75,3 \%$ dari variabel lain seperti faktor karakteristik individu deindividuasi, kekuasaan dan kepatuhan, provokasi, pengaruh obat-obatan terlarang (drug effect), personalitas, situasi, kondisi aversif, media massa, isyarat agresif, kehadiran orang lain, faktor keluarga, serta faktor lingkungan.

\section{Simpulan}

Berdasarkan hasil penelitian dapat diambil simpulan ada hubungan negatif antara kontrol diri dengan perilaku agresif pada remaja lakilaki peminum miras. Semakin baik kontrol diri pada remaja laki-laki peminum miras, maka semakin rendah perilaku agresif, dan sebaliknya, sehingga hipotesis dalam penelitian ini diterima Individu dengan kontrol diri yang baik akan dapat terhindar dari bentuk-bentuk perilaku agresif yang bertentangan dengan nilai-nilai yang berlaku di masyarakat.

\section{Ucapan Terima Kasih}

Pada kesempatan ini, terimakasih saya ucapkan kepada redaktur yang telah memberikan masukan yang berharga sehingga tulisan ini dapat disajikan di jurnal Institutio. Terimakasih juga saya ucapkan kepada seluruh dewan redaksi jurnal Institutio yang sudah memberikan ruang diskusi. Semoga bantuan dan dukungannya mendapatkan balasan yang sebanyak-banyaknya dari Tuhan kita Yesus Kristus, Amin.

\section{Pustaka Acuan}

Berkowitz, L. 2003. Emotional Behavior: Mengenali Perilaku dan Tindakan Kekerasan di Lingkungan Sekitar Kita dan Cara Penanggulangannya. Buku Kesatu. Alih Bahasa: Hartatni Woro Susiatni. Jakarta: PPM.

Borba, M. 2008. Membangun Kecerdasan Moral. Jakarta: PT. Gramedia.

Breakwell, G. M. 1998. Coping With Aggressive Behaviour. Alih Bahasa: Bernadus $\mathrm{H}$. Yogyakarta: Kanisius.

Calhoun, J. F dan Acocella, J. R. 1990. Psikology of Adjusment and Human Relationship. New York: Mc. Graw. Hill inc.

Dariyo, A. 2003. Psikologi Perkembangan Dewasa Muda. Jakarta: PT Grasindo Anggota Ikapi.

Dayakisni, T dan Hudainiah. 2008. Psikologi Sosial. Malang: UMM Press.

Goble, F. G. 1987. Mazhab Ketiga: Psikologi Humanistik Abraham Maslow. Alih Bahasa: A. Supratiknya. Yogyakarta: Kanisius.

Ghufron dan Rini, R. 2010. Teori-Teori Psikologi. Yogyakarta: AR-RUZZ Media Group. Kartono, K. 2005. Kenakalan Remaja: Jilid 2. Jakarta: Rajawali Press.

Krahe, B. 2005. Perilaku Agresif. Yogyakarta: Pustaka Pelajar. Mahmudah, S. 2010. Psikologi Sosial Sebuah Pengantar. Malang: UIN-Maliki Press.

Nenyok.2008.Geng NERO:PremanismePelajar.0\%20Premanisme $\% 20$ Pelajar $\% 20 \ll \% 20 S$ um'at, 29 Juni 2012).

Papalia, D. E., Old, S. W., dan Feldman, R. D. 2009. Perkembangan Manusia. Alih Bahasa: Brian Marwensdy. Jakarta: Salemba Humanika.

Ronal.2012.3 Tersangka Pembunuh di Pesta THM tangkap.

http://www.beritakotamakassar.com/index.php?o ption $=$ com content $\&$ view $=$ article \& id=606:3-tersangka-pembunuh-di-pestathm-

ditangkap\&catid=1:headline \&Itemid $=35$. (Minggu, 14 Oktober 2012).

Santrock, J. W. 2003. Adolescence. Edisi Keenam. Alih Bahasa: Drs. Shinto B. Adelar dan Sherly Saragih. Jakarta: Erlangga. 
Sarwono, W. S. 2002. Psikologi Sosial: Individu dan Teori- Teori Psikologi Sosial. Jakarta: Balai Pustaka.

Siddiqah, L. 2010. Pencegahan dan Penanganan Perilaku Agresif Melalui Pengelolaan Amarah (Anger Management). Jurnal Psikologi. Vol. 37. No. 1. Hal. 5064. Yogyakarta: Fakultas Psikologi Universitas Gadjah Mada.

Smet, B. 1994. Psikologi Kesehatan. Jakarta: Gramedia Widiasarana Indonesia.

Valentino. 2011. 4 Remaja Pesta Seks di Kelas, Lantaran Miras di Warung Oknum Polisi.

http://sosbud.kompasiana.com/2011/11/07/4remaja-pesta-seks-di-kelas-lantaran- mirasdari-warung-oknum-polisil. (Minggu, 14 Oktober 2012). 